\title{
Pontibacter actiniarum gen. nov., sp. nov., a novel member of the phylum 'Bacteroidetes', and proposal of Reichenbachiella gen. nov. as a replacement for the illegitimate prokaryotic generic name Reichenbachia Nedashkovskaya et al. 2003
}

Olga I. Nedashkovskaya, ${ }^{1}$ Seung Bum Kim, ${ }^{2}$ Makoto Suzuki, ${ }^{3}$

Lyudmila S. Shevchenko, ${ }^{1}$ Myung Sook Lee, ${ }^{4}$ Kang Hyun Lee, ${ }^{5}$ Myung Soo Park, ${ }^{5}$ Galina M. Frolova, ${ }^{1}$ Hyun Woo Oh, ${ }^{5}$ Kyung Sook Bae, ${ }^{5}$ Ho-Yong Park ${ }^{5}$ and Valery V. Mikhailov ${ }^{1}$

Correspondence

Olga I. Nedashkovskaya olganedashkovska@piboc.dvo.ru
${ }^{1}$ Pacific Institute of Bioorganic Chemistry of the Far-Eastern Branch of the Russian Academy of Sciences, Pr. 100 Let Vladivostoku 159, 690022, Vladivostok, Russia

${ }^{2}$ Department of Microbiology, Chungnam National University, 220 Gung-dong, Yusong, Daejon 305-764, Republic of Korea

${ }^{3}$ Tokyo Research Laboratories, Kyowa Hakko Kogyo Co. Ltd, 3-6-6 Asahi-machi, Machida-shi, Tokyo 194-8533, Japan

${ }^{4}$ Food Analysis and Research Institute, Suwon Women's College, 336-27 Sanggi-ri, Bongdam-sup, Hwasung-si, Kyonggi-Do 445-895, Republic of Korea

${ }^{5}$ Korea Institute of Bioscience and Biotechnology, 52 Oun-dong, Yusong, Daejon 305-333, Republic of Korea

The taxonomic position of a marine, gliding, pink-pigmented, aerobic, heterotrophic and Gramnegative bacterium was established using a polyphasic approach. 16S rRNA gene sequence analysis indicated that the strain was a member of the phylum 'Bacteroidetes' in which it occupied a separate lineage. The predominant cellular fatty acids were $\mathrm{C} 15: 0$ iso, $\mathrm{C} 17: 0$ iso $3-\mathrm{OH}$, summed feature 3 and summed feature 4 . The DNA G+C content was $48 \cdot 7 \mathrm{~mol} \%$. Phylogenetic evidence and the results of phenotypic, genotypic and chemotaxonomic analyses strongly support the assignment of the newly isolated bacterium as a member of a novel genus and species, for which the name Pontibacter actiniarum gen. nov., sp. nov. is proposed. The type strain is KMM $6156^{\top}$ $\left(=\right.$ KCTC $12367^{\top}=$ LMG $\left.23027^{\top}\right)$. It is also proposed that the illegitimate names Reichenbachia and Reichenbachia agariperforans are replaced with Reichenbachiella and Reichenbachiella agariperforans, respectively.
Marine bacteria of the phylum 'Bacteroidetes' with menaquinone 7 (MK-7) as their main respiratory quinone are frequently found in marine ecosystems. They can move by means of gliding or be non-motile and are rod-shaped or ring-like. The majority of them have been isolated from sea water, sediment or algae (Bowman et al., 2003; Brettar et al.,

Published online ahead of print on 12 August 2005 as DOI 10.1099/ ijs.0.63819-0.

Abbreviation: MK-7, menaquinone 7.

The GenBank/EMBL/DDBJ accession number for the 16S rRNA gene sequence of Pontibacter actiniarum sp. nov. KMM $6156^{\top}$ is AY989908.

A scanning electron micrograph of cells of strain $\mathrm{KMM} 6156^{\top}$ is available as a supplementary figure in IJSEM Online. 2004a, b; Nedashkovskaya et al., 2003, 2004, 2005a; Raj \& Maloy, 1990; Van Trappen et al., 2004; Yi \& Chun, 2004; Yoon et al., 2004, 2005a, b, c). Currently, only two species with validly published names that belong to the MK-7 phylogenetic cluster, Cyclobacterium marinum (formerly Flectobacillus marinus) and Roseivirga echinicomitans, have been isolated from marine animals: sea urchins of Dendraster sp. and Strongylocentrotus intermedius, respectively (Larkin \& Borrall, 1984; Nedashkovskaya et al., 2005b).

In this study, we report the isolation and identification of a strain of heterotrophic, Gram-negative, aerobic, gliding and pink-coloured bacteria associated with a marine coelenterate. Based on a polyphasic study of strain KMM $6156^{\mathrm{T}}$, 
including phylogenetic, genotypic, chemotaxonomic and phenotypic analyses, a novel genus, Pontibacter, is proposed.

Strain KMM $6156^{\mathrm{T}}$ was isolated from unidentified actinians, collected from a depth of $118 \mathrm{~m}$ in Rudnaya Bay, East Sea (also known as the Sea of Japan), Pacific Ocean, during July 2003. For strain isolation, $0 \cdot 1 \mathrm{ml}$ homogenate of actinian tissues was transferred onto plates of marine agar 2216 (Difco). After primary isolation and purification, strains were cultivated at $28^{\circ} \mathrm{C}$ on the same medium and stored at $-80^{\circ} \mathrm{C}$ in marine broth (Difco) supplemented with $20 \%$ $(\mathrm{v} / \mathrm{v})$ glycerol.

\section{Phylogenetic analysis}

Genomic DNA extraction, PCR and sequencing of the 16S rRNA gene followed previous procedures (Kim et al., 1998). Sequence data obtained were aligned with those of representative members of the phylum 'Bacteroidetes' by using PHYDIT version 3.2 (http://plaza.snu.ac.kr/ jchun/ phydit/). Phylogenetic trees were inferred using suitable programs from the PHYLIP package (Felsenstein, 1993). Phylogenetic distances were calculated using the Kimura two-parameter model (Kimura, 1980) and trees were constructed on the basis of the neighbour-joining (Saitou \& Nei, 1987), least-squares (Fitch \& Margoliash, 1967) and maximum-likelihood (Felsenstein, 1993) algorithms. Bootstrap analysis was performed with 1000 resampled datasets by using the SEQBOOT and CONSENSE programs of the PHYLIP package.

Phylogenetic analysis of the almost-complete 16S rRNA gene sequence of strain KMM $6156^{\mathrm{T}}$ (1435 nucleotides) revealed that the strain belongs to the phylum 'Bacteroidetes', in which it forms a distinct lineage (Fig. 1). The type strain of the single species of the genus Adhaeribacter, Adhaeribacter aquaticus MBRG $1.5^{\mathrm{T}}$, was the closest relative of strain KMM $6156^{\mathrm{T}}$, with a $16 \mathrm{~S}$ rRNA gene sequence similarity of $89 \cdot 2 \%$.

\section{Genotypic methods}

DNA was isolated following the method of Marmur (1961) and the DNA G $+\mathrm{C}$ content was determined by the thermal denaturation method (Marmur \& Doty, 1962). The DNA $\mathrm{G}+\mathrm{C}$ composition of KMM $6156^{\mathrm{T}}$ was $48 \cdot 7 \mathrm{~mol} \%$.

\section{Chemotaxonomic methods}

For the determination of the cellular fatty acid methyl ester content, strain KMM $6156^{\mathrm{T}}$ was grown on marine agar at $25^{\circ} \mathrm{C}$ for $48 \mathrm{~h}$. FAME analysis was carried out according to the standard Microbial Identification System protocol (Microbial ID).

Strain KMM $6156^{\mathrm{T}}$ is characterized by the presence of the predominant branched-chain saturated and unsaturated fatty acids $\mathrm{C} 15: 1$ iso $(28 \cdot 8 \%), \mathrm{C} 17: 0$ iso $3-\mathrm{OH}(6 \cdot 5 \%)$, summed feature 3 (14.7\%; comprising $\mathrm{C} 15: 0$ iso $2-\mathrm{OH}$

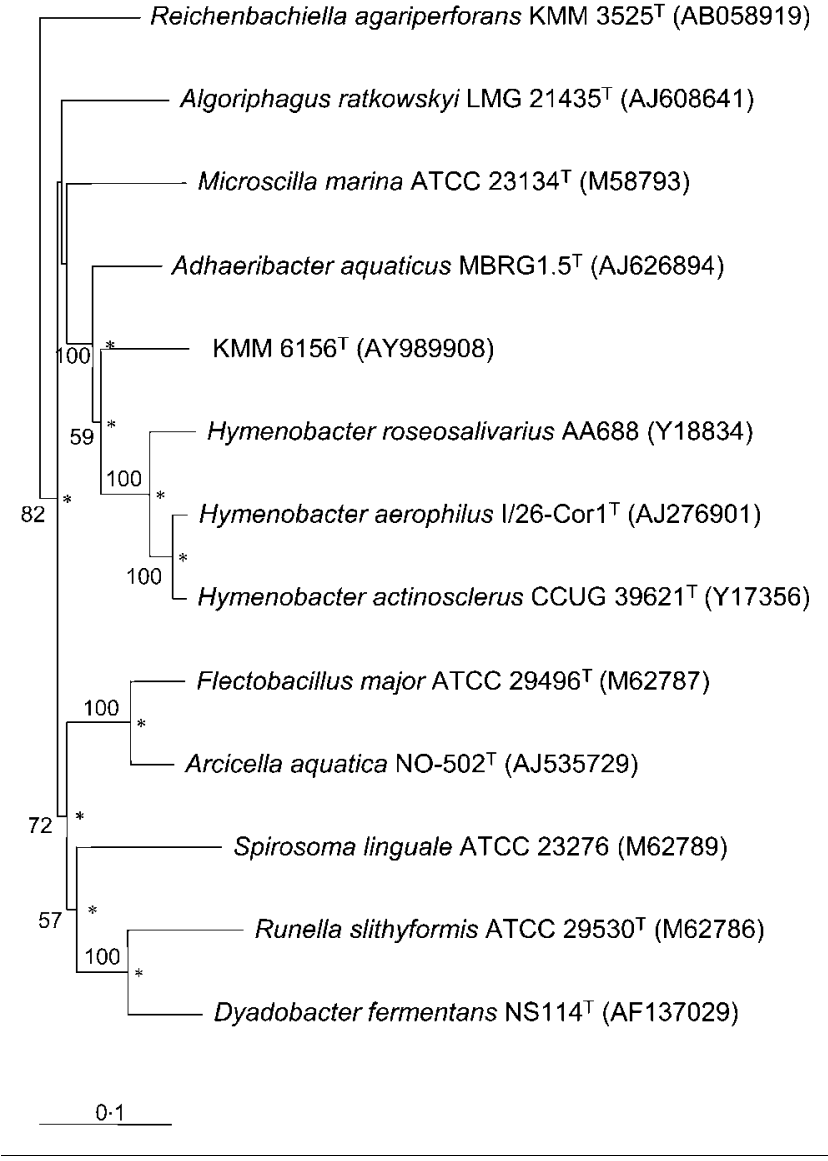

Fig. 1. Neighbour-joining phylogenetic tree based on the $16 \mathrm{~S}$ rRNA gene sequences of strain KMM $6156^{\top}$ and representative members of the phylum 'Bacteroidetes'. Asterisks indicate branches that were also recovered using the maximumlikelihood algorithm. Numbers at nodes indicate bootstrap values (\%). Bar, 0.01 substitutions per nucleotide position.

and/or C16: $1 \omega 7)$ and summed feature $4(31 \cdot 3 \%$; consisting of $\mathrm{C} 17: 1$ iso I and/or C17:1 anteiso B) (Table 1$)$.

Isoprenoid quinones were extracted from lyophilized cells and analysed as described by Akagawa-Matsushita et al. (1992). Menaquinones were detected by monitoring at $270 \mathrm{~nm}$ and were identified by comparison with known quinones from the reference strain Cyclobacterium marinum LMG $13164^{\mathrm{T}}$. The main isoprenoid quinone was MK-7.

\section{Phenotypic methods}

The physiological and biochemical properties of strain KMM $6156^{\mathrm{T}}$ were examined as described by Nedashkovskaya et al. $(2003,2004)$. Physiological and biochemical features of KMM $6156^{\mathrm{T}}$ were determined using the API $20 \mathrm{E}$, API 20NE, API ZYM and API $50 \mathrm{CH}$ galleries (bioMérieux) and Biolog GN2 Microplate system (Biolog) according to the manufacturers' instructions. Susceptibility to antibiotics was tested as described previously (Nedashkovskaya et al., 2003) and additional discs containing chloramphenicol 
Table 1. Cellular fatty acid content of Pontibacter actiniarum $\mathrm{KMM} 6156^{\top}$ and its closest relatives from the phylum 'Bacteroidetes'

Taxa: 1, Pontibacter actiniarum KMM $6156^{\mathrm{T}}$; 2, Adhaeribacter aquaticus; 3, Hymenobacter actinosclerus; 4, Hymenobacter aerophilus. Data from Buczolits et al. (2002), Nedashkovskaya et al. (2004), Rickard et al. (2005) and this study. Values are percentages and values of less than $1 \%$ are not shown. Summed feature 2 consisted of one or more of the following fatty acids which could not be separated by the Microbial Identification System: $\mathrm{C} 15: 1$ iso I and $\mathrm{C} 13: 03-\mathrm{OH}$. Summed feature 3 consisted of one or more of the following fatty acids: $\mathrm{C} 15: 0$ iso $2-\mathrm{OH}, \mathrm{C} 16: 1 \omega 7 c$ and C16:1 $1 \omega 7 t$. Summed feature 4 consisted of one or more of the following fatty acids: $\mathrm{C} 17: 1$ iso $\mathrm{I}$ and $\mathrm{C} 17: 1$ anteiso $\mathrm{B}$. Summed feature 5 consisted of one or more of the following fatty acids: $\mathrm{C} 18: 0$ anteiso and $\mathrm{C} 18: 2 \omega 6,9 c$.

\begin{tabular}{|lcccc|}
\hline Fatty acid & $\mathbf{1}$ & $\mathbf{2}$ & $\mathbf{3}$ & $\mathbf{4}$ \\
\hline $\mathrm{C} 10: 0$ iso & - & $1 \cdot 2$ & - & - \\
$\mathrm{C} 15: 0$ iso & $28 \cdot 8$ & $22 \cdot 5$ & $22 \cdot 3$ & $10 \cdot 8-15 \cdot 0$ \\
$\mathrm{C} 15: 0$ anteiso & $0 \cdot 1$ & $4 \cdot 4$ & $25 \cdot 8$ & $18 \cdot 6-22 \cdot 3$ \\
$\mathrm{C} 15: 1 \omega 6 c$ & $0 \cdot 3$ & - & $0 \cdot 8$ & $0 \cdot 8-1 \cdot 2$ \\
$\mathrm{C} 16: 1 \omega 5 c$ & $0 \cdot 8$ & $16 \cdot 9$ & $3 \cdot 7$ & $6 \cdot 6-7 \cdot 9$ \\
$\mathrm{C} 16: 1$ isoH & $0 \cdot 5$ & - & $1 \cdot 5$ & $1 \cdot 4-1 \cdot 5$ \\
$\mathrm{C} 16: 0$ & $0 \cdot 2$ & - & - & $1 \cdot 6-1 \cdot 7$ \\
$\mathrm{C} 15: 0$ iso 2-OH & - & $16 \cdot 5$ & $0 \cdot 8$ & - \\
$\mathrm{C} 15: 0$ iso 3-OH & $3 \cdot 0$ & $3 \cdot 1$ & $1 \cdot 6$ & $1 \cdot 3-1 \cdot 6$ \\
$\mathrm{C} 17: 1 \omega 6 c$ & $1 \cdot 4$ & $5 \cdot 1$ & $0 \cdot 7$ & $0-0 \cdot 7$ \\
$\mathrm{C} 17: 0$ iso & $2 \cdot 2$ & - & $1 \cdot 8$ & $2 \cdot 7-4 \cdot 5$ \\
$\mathrm{C} 17: 0$ anteiso & - & - & $0 \cdot 7$ & $1 \cdot 3-2 \cdot 3$ \\
$\mathrm{C} 17: 0$ iso 3-OH & $6 \cdot 5$ & $12 \cdot 1$ & $3 \cdot 1$ & $2 \cdot 6-3 \cdot 5$ \\
$\mathrm{C} 17: 0$ iso 2-OH & - & - & $2 \cdot 0$ & - \\
$\mathrm{C} 17: 0$ 2-OH & - & - & - & $0 \cdot 8-1 \cdot 3$ \\
Summed feature 2 & $2 \cdot 3$ & - & $2 \cdot 3$ & $0 \cdot 8-1 \cdot 4$ \\
Summed feature 3 & $14 \cdot 7$ & - & $13 \cdot 1$ & $21 \cdot 4-22 \cdot 3$ \\
Summed feature 4 & $31 \cdot 3$ & $11 \cdot 2$ & $19 \cdot 9$ & $17 \cdot 7-18 \cdot 8$ \\
Summed feature 5 & $1 \cdot 8$ & - & - & - \\
& & & & \\
\hline
\end{tabular}

$(30 \mu \mathrm{g})$, doxycycline $(10 \mu \mathrm{g})$ and erythromycin $(15 \mu \mathrm{g})$ were used. Gliding motility was determined as described by Bowman (2000). To study cell morphology, samples were fixed in $2.5 \%$ paraformaldehyde-glutaraldehyde mixture buffered with $0 \cdot 1 \mathrm{M}$ phosphate $(\mathrm{pH} 7 \cdot 2)$ for $2 \mathrm{~h}$, fixed in $1 \%$ osmium tetroxide in the same buffer for $1 \mathrm{~h}$, dehydrated in graded ethanol and substituted by isoamyl acetate. Samples were then dried at the critical point in $\mathrm{CO}_{2}$. Finally, the samples were sputtered with gold in a sputter coater (SC502; Polaron) and observed using a scanning electron microscope (SEM 515; Philips). Cells of KMM $6156^{\mathrm{T}}$ ranged from 0.3 to $0.4 \mu \mathrm{m}$ in width and from $1 \cdot 2$ to $1.9 \mu \mathrm{m}$ in length (see Supplementary Fig. S1 in IJSEM Online).

Strain KMM $6156^{\mathrm{T}}$ was Gram-negative, chemo-organotrophic, aerobic, pink-pigmented and motile by gliding. The main physiological and biochemical characteristics of the strain are given in Table 2 and the species description. The features that differentiate strain KMM $6156^{\mathrm{T}}$ from related members of the phylum 'Bacteroidetes' are shown in Table 2. Strain KMM $6156^{\mathrm{T}}$ differs from its closest phylogenetic neighbour, the freshwater bacterium Adhaeribacter aquaticus, by its abilities to move by gliding and to hydrolyse agar, by the absence of amylase activity and by a higher DNA G $+\mathrm{C}$ content ( $48 \cdot 7 \mathrm{~mol} \%$ for KMM $6156^{\mathrm{T}}$ compared with $40 \cdot 0 \mathrm{~mol} \%$ for A. aquaticus).

Strain KMM $6156^{\mathrm{T}}$ could be distinguished from its closest relatives on the basis of phenotypic features, fatty acid content and significant phylogenetic distinctiveness. Low 16S rRNA gene sequence similarities of strain KMM $6156^{\mathrm{T}}$ with the other members of the phylum 'Bacteroidetes' described to date $(78 \cdot 5-89 \cdot 2 \%)$ clearly demonstrate that the newly isolated bacterium represents a novel genus.

Thus, the polyphasic data presented in this paper support the conclusion that strain KMM $6156^{\mathrm{T}}$ can not be affiliated to any currently described taxa of the phylum 'Bacteroidetes'. Consequently, we propose that strain KMM $6156^{\mathrm{T}}$ should be placed in a novel genus as Pontibacter actiniarum gen. nov., sp. nov.

Previously, we described the genus Reichenbachia and the novel species Reichenbachia agariperforans to accommodate strain KMM $3525^{\mathrm{T}}$. However, the prokaryotic genus name Reichenbachia Nedashkovskaya et al. 2003 is illegitimate because it is a later homonym of the plant genus name Reichenbachia Sprengel 1823 [Principle 2 of the Bacteriological Code (1990 Revision)] and a later homonym of the insect genus name Reichenbachia Leach 1825 [Principle 2 of the Bacteriological Code (1990 Revision)]. Consequently, we propose to replace the names Reichenbachia and Reichenbachia agariperforans with Reichenbachiella and Reichenbachiella agariperforans, respectively.

According to Nedashkovskaya et al. (2003), strain KMM $3525^{\mathrm{T}}$ does not utilize carbohydrates, but the addition of sea water $(50 \%)$ to the medium used for the sugar oxidation test revealed the formation of acid from L-arabinose and Lfucose. Testing of strain KMM $3525^{\mathrm{T}}$ using the API $50 \mathrm{CH}$ gallery (bioMérieux) also indicated acid formation from aesculin and arbutin. These findings are included in the description of Reichenbachiella agariperforans.

\section{Description of Pontibacter gen. nov.}

Pontibacter (Pon.ti.bac'ter. L. n. pontus the sea; N.L. masc. n. bacter from Gr. neut. n. baktron rod; N.L. masc. n. Pontibacter a marine bacterium).

Rod-shaped cells, motile by means of gliding. Gramnegative. Do not form endospores. Aerobic. Produce non-diffusible carotenoid pigments. Chemo-organotrophic. Cytochrome oxidase-, catalase- and alkaline phosphatasepositive. The major respiratory quinone is MK-7. The main cellular fatty acids are straight-chain unsaturated and branched-chain unsaturated fatty acids $\mathrm{C} 15: 1$ iso, $\mathrm{C} 17: 0$ iso 3-OH, summed feature 3 (comprising $\mathrm{C} 15: 0$ iso $2-\mathrm{OH}$

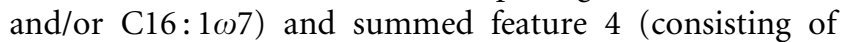


Table 2. Phenotypic characteristics that separate Pontibacter actiniarum $\mathrm{KMM} 6156^{\top}$ and its close relatives belonging to the phylum 'Bacteroidetes'

Taxa: 1, Pontibacter actiniarum KMM $6156^{\mathrm{T}}$; 2, Adhaeribacter aquaticus; 3, Hymenobacter; 4, Microscilla marina; 5, Algoriphagus. Data from Reichenbach (1989), Hirsch et al. (1998), Collins et al. (2000), Buczolits et al. (2002), Bowman et al. (2003), Nedashkovskaya et al. (2004), Van Trappen et al. (2004), Rickard et al. (2005), Yoon et al. (2005b) and this study. M, Marine; T, terrestrial; A, air; FW, fresh water; P, pink; R, red; RP, red-pink; O, orange; OR, orange-red; V, variable; ND, not detected.

\begin{tabular}{|c|c|c|c|c|c|}
\hline Characteristic & 1 & 2 & 3 & 4 & 5 \\
\hline Habitat & M & FW & $\mathrm{T}, \mathrm{A}$ & M & M \\
\hline \multirow[t]{2}{*}{ Cell size $(\mu \mathrm{m})$} & $0 \cdot 3-0 \cdot 4 \times$ & $0 \cdot 9-1 \cdot 7 \times$ & $0 \cdot 4-1 \cdot 0 \times$ & $0 \cdot 5-0 \cdot 6 \times$ & $0 \cdot 3-0 \cdot 7 \times$ \\
\hline & $1 \cdot 2-1 \cdot 9$ & $2 \cdot 8-4 \cdot 1$ & $1 \cdot 3-5 \cdot 0$ & $>150$ & $1 \cdot 0-10 \cdot 0$ \\
\hline Gliding motility & + & - & - & + & - \\
\hline Colony colour & $\mathrm{P}$ & $\mathrm{P}$ & $\mathrm{RP}, \mathrm{R}$ & $\mathrm{O}$ & $\mathrm{O}, \mathrm{OR}, \mathrm{P}$ \\
\hline$\alpha$-Galactosidase & - & + & - & ND & + \\
\hline$\beta$-Galactosidase & + & + & - & ND & + \\
\hline Salinity range $(\%)$ & $0-10$ & $0-4$ & $0-2$ & $1-2$ & $0-10$ \\
\hline $\begin{array}{l}\text { Temperature } \\
\text { range }\left({ }^{\circ} \mathrm{C}\right)\end{array}$ & $6-43$ & $4-37$ & $-0 \cdot 5$ to 42 & 35 & -2 to 41 \\
\hline \multicolumn{6}{|l|}{ Hydrolysis of: } \\
\hline Aesculin & + & ND & - & $\mathrm{ND}$ & + \\
\hline Agar & + & - & - & - & $\mathrm{V}$ \\
\hline Starch & - & + & + & - & $\mathrm{V}$ \\
\hline Trypsin & + & ND & - & ND & + \\
\hline Tween 80 & - & ND & + & ND & $\mathrm{V}$ \\
\hline $\begin{array}{l}\text { DNA G }+\mathrm{C} \\
\text { content }(\mathrm{mol} \%)\end{array}$ & $48 \cdot 7$ & $40 \cdot 0$ & $55-64$ & $42 \cdot 0$ & $35-42$ \\
\hline
\end{tabular}

C17: 1 iso I and/or C17 : 1 anteiso B). As determined by $16 \mathrm{~S}$ rRNA gene sequence analysis, the genus Pontibacter is a member of the phylum 'Bacteroidetes'. The type species is Pontibacter actiniarum.

\section{Description of Pontibacter actiniarum sp. nov.}

Pontibacter actiniarum (ac.ti.ni.a'rum. N.L. gen. pl. n. actiniarum of sea anemones or related animals).

Displays the following properties in addition to those given in the genus description. Cells range from 0.3 to $0 \cdot 4 \mu \mathrm{m}$ in width and from 1.2 to $1.9 \mu \mathrm{m}$ in length. On marine agar, colonies are circular, 2-3 mm diameter, convex, shiny, pink and smooth. Does not require $\mathrm{Na}^{+}$or sea water for growth. Growth occurs at $6-43^{\circ} \mathrm{C}$; optimal temperature is $25-28^{\circ} \mathrm{C}$. Growth occurs at $0-10 \% \mathrm{NaCl}$. No pigments of flexirubin type are formed. Decomposes agar (weakly), gelatin, DNA and Tweens 20 and 40. Does not hydrolyse casein, starch, Tween 80, cellulose (CM-cellulose or filter paper) or chitin. Forms acid from aesculin and arbutin (API $50 \mathrm{CH}$ gallery; bioMérieux). Does not form acid from L-arabinose, Dcellobiose, D-fructose, L-fucose, D-galactose, D-glucose, D-lactose, D-maltose, D-melibiose, L-raffinose, L-rhamnose, L-sorbose, D-sucrose, DL-xylose, $\mathrm{N}$-acetylglucosamine, glycerol, adonitol, dulcitol, inositol or mannitol. Biolog GN2 tests show that the type strain utilizes dextrin, glycogen, methyl pyruvate, $\alpha$-ketovaleric acid, DL-lactic acid, alaninamide, L-alanine, L-asparagine, L-aspartic acid, L-glutamic acid, L-proline, methyl $\beta$-D-glucoside, $\alpha$-ketobutyric acid, succinamic acid, L-alanyl-glycine, glycyl-L-aspartic acid and L-threonine. Does not utilize $\alpha$-cyclodextrin, Tween $80, N$ acetyl-D-galactosamine, $\mathrm{N}$-acetyl-D-glucosamine, adonitol, L-arabinose, L-arabitol, cellobiose, i-erythritol, D-fructose, L-fucose, D-galactose, gentiobiose, $\alpha$-D-glucose, myo-inositol, $\alpha$-lactose, $\alpha$-D-lactose, lactulose, maltose, D-mannitol, Dmannose, D-melibiose, psicose, D-raffinose, L-rhamnose, Dsorbitol, sucrose, D-trehalose, turanose, xylitol, monomethyl succinate, acetic acid, cis-aconitic acid, citric acid, formic acid, D-galactonic acid, D-galacturonic acid, D-gluconic acid, D-glucosaminic acid, D-glucuronic acid, $\alpha-, \beta$ - and $\gamma$ hydroxybutyric acids, $p$-hydroxyphenylacetic acid, itaconic acid, $\alpha$-ketoglutaric acid, malonic acid, propionic acid, quinic acid, D-saccharic acid, sebacic acid, succinic acid, bromosuccinic acid, glucuronamide, D-alanine, glycyl-L-glutamic acid, L-histidine, hydroxy-L-proline, L-leucine, L-ornithine, Lphenylalanine, L-pyroglutamic acid, D-serine, L-serine, DLcarnitine, $\gamma$-aminobutyric acid, urocanic acid, inosine, uridine, thymidine, phenylethylamine, putrescine, 2-aminoethanol, 2,3butanediol, glycerol, DL- $\alpha$-glycerol phosphate, glucose 1phosphate and glucose 6-phosphate. Nitrate is not reduced. Indole, $\mathrm{H}_{2} \mathrm{~S}$ and acetoin (Voges-Proskauer reaction) production is negative. According to the API ZYM gallery (bioMérieux), produces $\beta$-galactosidase, acid phosphatase, esterase lipase (C8), leucine and valine arylamidases, trypsin, naphthol-AS-BI-phosphohydrolase, $\alpha$-glucosidase and $N$ acetyl- $\beta$-glucosaminidase but not esterase (C4), lipase (C14), 
cystine arylamidase, $\alpha$-chymotrypsin, $\alpha$-galactosidase, $\beta$ glucosidase, $\beta$-glucuronidase, $\alpha$-mannosidase or $\alpha$-fucosidase. The predominant fatty acids are $\mathrm{C} 15: 1$ iso $(28 \cdot 8 \%), \mathrm{C} 17: 0$ iso 3-OH (6.5\%), summed feature 3 ( $14 \cdot 7 \%$; comprising C15: 0 iso $2-\mathrm{OH}$ and/or $\mathrm{C} 16: 1 \omega 7)$ and summed feature $4(31 \cdot 3 \%$; consisting of C17: 1 iso I and/or C17: 1 anteiso B). Susceptible to ampicillin, benzylpenicillin, chloramphenicol, doxycycline, erythromycin, kanamycin, carbenicillin, lincomycin, oleandomycin and tetracycline. Resistant to gentamicin, neomycin, polymixin B and streptomycin. The DNA G+C content is $48 \cdot 7 \mathrm{~mol} \%$.

The type strain, KMM $6156^{\mathrm{T}}\left(=\mathrm{KCTC} 12367^{\mathrm{T}}=\mathrm{LMG}\right.$ $\left.23027^{\mathrm{T}}\right)$, was isolated from unidentified actinians collected in Rudnaya Bay, Pacific Ocean.

\section{Description of Reichenbachiella gen. nov. (previous illegitimate name Reichenbachia Nedashkovskaya et al. 2003)}

Reichenbachiella (Rei.chen.bach.i.el'la. N.L. fem. dim. n. Reichenbachiella named in honour of Hans Reichenbach, a German microbiologist who has made a great contribution to the taxonomy of bacteria belonging to the phylum 'Bacteroidetes').

Rod-shaped, motile by gliding. Gram-negative. Do not form endospores. Aerobic. Produce non-diffusible carotenoid pigments. Chemo-organotrophic. Cytochrome oxidase-, catalase- and alkaline phosphatase-positive. The major respiratory quinone is MK-7. The main cellular fatty acids are straight-chain unsaturated and branched-chain saturated fatty acids $\mathrm{C} 15: 0$ iso, $\mathrm{C} 16: 1 \omega 5 c$ and summed feature

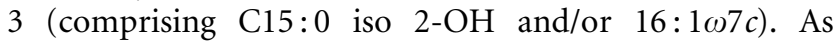
determined by $16 \mathrm{~S}$ rRNA gene sequence analysis, the genus Reichenbachiella is a member of the phylum 'Bacteroidetes'. The type species is Reichenbachiella agariperforans.

\section{Description of Reichenbachiella agariperforans comb. nov. (illegitimate basonym Reichenbachia agariperforans Nedashkovskaya et al. 2003)}

Reichenbachiella agariperforans [a.ga.ri.per.fo'rans. N.L. n. agarum agar (algal polysaccharide); L. part. adj. perforans perforating (making holes); N.L. part. adj. agariperforans making holes in agar, bacterium making deep hollows in agar].

The description is as given by Nedashkovskaya et al. (2003) with the following additional characteristics. The type strain can form acid from L-arabinose, D-cellobiose, D-glucose and $\mathrm{N}$-acetylglucosamine. According to the API $50 \mathrm{CH}$ gallery (bioMérieux), it can form acid from arbutin and aesculin. Can produce leucine- and valine-arylamidases, trypsin, naphthol-AS-BI-phosphohydrolase, $\alpha$ - and $\beta$-galactosidases, $\alpha$ - and $\beta$-glucosidases, $N$-acetyl- $\beta$-glucosaminidase and alkaline and acid phosphatases, but not esterase (C4), esterase lipase (C8), lipase (C14), cystine arylamidase, $\alpha$-chymotrypsin, $\beta$-glucuronidase, $\alpha$-mannosidase or $\alpha$-fucosidase. Flexirubin pigments are produced. The predominant fatty acids are C15: 0 iso $(28 \cdot 6 \%), \mathrm{C} 16: 1 \omega 5 c(21 \cdot 9 \%)$ and summed feature 3 (20.7\%; comprising $\mathrm{C} 15: 0$ iso $2-\mathrm{OH}$ and/or $\mathrm{C} 16: 1 \omega 7)$.

The type strain, KMM $3525^{\mathrm{T}}\left(=\mathrm{NBRC} 16625^{\mathrm{T}}=\mathrm{JCM}\right.$ $11238^{\mathrm{T}}$ ), was isolated from sea water collected in Amursky Bay, Pacific Ocean.

\section{Acknowledgements}

We are deeply grateful to Dr Jean Euzéby for his useful advice on the species names justification. This research was supported by grants from the Federal Agency for Science and Innovations of the Ministry for Education and Sciences of the Russian Federation no. RI-26/109 (22.16) and 112/001/724, Russian Foundation for Basic Research no. 05-04-48211 and Presidium of the Russian Academy of Sciences 'Molecular and Cell Biology'. S. B. K., M. S. L. and M. S. P. acknowledge support from the Eco-Technopia 21 project of the Ministry of Environment and K.H.L. and K.S.B. are grateful to the KRIBB Research Initiative Program.

\section{References}

Akagawa-Matsushita, M., Itoh, T., Katayama, Y., Kuraishi, H. \& Yamasato, K. (1992). Isoprenoid quinone composition of some marine Alteromonas, Marinomonas, Deleya, Pseudomonas and Shewanella species. J Gen Microbiol 138, 2275-2281.

Bowman, J. P. (2000). Description of Cellulophaga algicola sp. nov., isolated from the surfaces of Antarctic algae, and reclassification of Cytophaga uliginosa (ZoBell and Upham 1944) Reichenbach 1989 as Cellulophaga uliginosa comb. nov. Int J Syst Evol Microbiol 50, 1861-1868.

Bowman, J. P., Nichols, C. M. \& Gibson, J. A. E. (2003). Algoriphagus ratkowskyi gen. nov., sp. nov., Brumimicrobium glaciale gen. nov., sp. nov., Cryomorpha ignava gen. nov., sp. nov. and Crocinitomix catalasitica gen. nov., sp. nov., novel flavobacteria isolated from various polar habitats. Int J Syst Evol Microbiol 53, 1343-1355.

Brettar, I., Christen, R. \& Höfle, M. G. (2004a). Belliella baltica gen. nov., sp. nov., a novel marine bacterium of the CytophagaFlavobacterium-Bacteroides group isolated from surface water of the central Baltic Sea. Int J Syst Evol Microbiol 54, 65-70.

Brettar, I., Christen, R. \& Höfle, M. G. (2004b). Aquiflexum balticum gen. nov., sp. nov., a novel marine bacterium of the CytophagaFlavobacterium-Bacteroides group isolated from surface water of the central Baltic Sea. Int J Syst Evol Microbiol 54, 2335-2341.

Buczolits, S., Denner, E. B. M., Vybiral, D., Wieser, M., Kämpfer, P. \& Busse, H. J. (2002). Classification of three airborne bacteria and proposal of Hymenobacter aerophilus sp. nov. Int J Syst Evol Microbiol 52, 445-456.

Collins, M. D., Hutson, R. A., Grant, I. R. \& Patterson, M. F. (2000). Phylogenetic characterization of a novel radiation-resistant bacterium from irradiated pork: description of Hymenobacter actinosclerus sp. nov. Int J Syst Evol Microbiol 50, 731-734.

Felsenstein, J. (1993). PHYLIP (phylogeny inference package), version 3.5c. Distributed by the author. Department of Genome Sciences, University of Washington, Seattle, USA.

Fitch, W. M. \& Margoliash, E. (1967). Construction of phylogenetic trees. Science 155, 279-284.

Hirsch, P., Ludwig, W., Hethke, C., Sittig, M., Hoffmann, B. \& Gallikowski, C. A. (1998). Hymenobacter roseosalivarius gen. nov., sp. nov. from continental Antarctica soils and sandstone: bacteria of the 
Cytophaga/Flavobacterium/Bacteroides line of phylogenetic descent. Syst Appl Microbiol 21, 374-383.

Kim, S. B., Falconer, C., Williams, E. \& Goodfellow, M. (1998). Streptomyces thermocarboxydovorans sp. nov. and Streptomyces thermocarboxydus sp. nov., two moderately thermophilic carboxydotrophic species isolated from soil. Int J Syst Bacteriol 48, 59-68.

Kimura, M. (1980). A simple method for estimating evolutionary rates of base substitutions through comparative studies of nucleotide sequences. J Mol Evol 16, 111-120.

Larkin, J. M. \& Borrall, R. (1984). Genus III. Flectobacillus Larkin, Williams and Taylor 1977, 152 $2^{\mathrm{AL}}$. In Bergey's Manual of Systematic Bacteriology, vol. 1, pp. 129-132. Edited by N. R. Krieg \& J. C. Holt. Baltimore: Williams \& Wilkins.

Marmur, J. (1961). A procedure for the isolation of deoxyribonucleic acid from microorganisms. J Mol Biol 3, 208-218.

Marmur, J. \& Doty, P. (1962). Determination of the base composition of deoxyribonucleic acid from its thermal denaturation temperature. J Mol Biol 5, 109-118.

Nedashkovskaya, O. I., Suzuki, M., Vysotskii, M. V. \& Mikhailov, V. V. (2003). Reichenbachia agariperforans gen. nov., sp. nov., a novel marine bacterium in the phylum Cytophaga-FlavobacteriumBacteroides. Int J Syst Evol Microbiol 53, 81-85.

Nedashkovskaya, O. I., Vancanneyt, M., Van Trappen, S. \& 7 other authors (2004). Description of Algoriphagus aquimarinus sp. nov., Algoriphagus chordae sp. nov. and Algoriphagus winogradskyi sp. nov., from sea water and algae, transfer of Hongiella halophila Yi and Chun 2004 to the genus Algoriphagus as Algoriphagus halophilus comb. nov. and emended descriptions of the genera Algoriphagus Bowman et al. 2003 and Hongiella Yi and Chun 2004. Int J Syst Evol Microbiol 54, 1757-1764.

Nedashkovskaya, O. I., Kim, S. B., Lee, D. H., Lysenko, A. M., Shevchenko, L. S., Frolova, G. M., Mikhailov, V. V., Lee, K. H. \& Bae, K. S. (2005a). Roseivirga ehrenbergii gen. nov., sp. nov., a novel marine bacterium of the phylum 'Bacteroidetes', isolated from the green alga Ulva fenestrata. Int J Syst Evol Microbiol 55, 231-234.

Nedashkovskaya, O. I., Kim, S. B., Lysenko, A. M., Park, M. S., Mikhailov, V. V., Bae, K. S. \& Park, H. Y. (2005b). Roseivirga echinicomitans sp. nov., a novel marine bacterium isolated from the sea urchin Strongylocentrotus intermedius, and emended description of the genus Roseivirga. Int J Syst Evol Microbiol 55, 1797-1800.
Nedashkovskaya, O. I., Kim, S. B., Lee, M. S., Park, M. S., Lee, K. H., Lysenko, A. M., Oh, H. W., Mikhailov, V. V. \& Bae, K. S. (2005c). Cyclobacterium amurskyense sp. nov., a novel marine bacterium isolated from sea water. Int J Syst Evol Microbiol 55, 2391-2394.

Raj, H. D. \& Maloy, S. R. (1990). Proposal of Cyclobacterium marinus gen. nov., comb. nov. for a marine bacterium previously assigned to the genus Flectobacillus. Int J Syst Bacteriol 40, 337-347.

Reichenbach, H. (1989). The order Cytophagales Leadbetter 1974, $99^{\mathrm{AL}}$. In Bergey's Manual of Systematic Bacteriology, vol. 3, pp. 2011-2073. Edited by J. T. Staley, M. P. Bryant, N. Pfennig \& J. G. Holt. Baltimore: Williams \& Wilkins.

Rickard, A. H., Stead, A. T., O’May, G. A., Lindsay, S., Banner, M., Handley, P. S. \& Gilbert, P. (2005). Adhaeribacter aquaticus gen. nov., sp. nov., a Gram-negative isolate from a potable water biofilm. Int J Syst Evol Microbiol 55, 821-829.

Saitou, N. \& Nei, M. (1987). The neighbor-joining method: a new method for reconstructing phylogenetic trees. Mol Biol Evol 4, 406-425.

Van Trappen, S., Vandecandelaere, I., Mergaert, J. \& Swings, J. (2004). Algoriphagus antarcticus sp. nov., a novel psychrophile from microbial mats in Antarctic lakes. Int J Syst Evol Microbiol 54, 1969-1973.

Yi, H. \& Chun, J. (2004). Hongiella mannitolivorans gen. nov., sp. nov., Hongiella halophila sp. nov. and Hongiella ornithinivorans sp. nov., isolated from tidal flat sediment. Int J Syst Evol Microbiol 54, 157-162.

Yoon, J.-H., Yeo, S.-H. \& Oh, T.-K. (2004). Hongiella marincola sp. nov., isolated from sea water of the East Sea in Korea. Int J Syst Evol Microbiol 54, 1845-1848.

Yoon, J.-H., Kang, S.-J., Lee, C.-H. \& Oh, T.-K. (2005a). Marinicola seohaensis gen. nov., sp. nov., isolated from sea water of the Yellow Sea, Korea. Int J Syst Evol Microbiol 55, 859-863.

Yoon, J.-H., Kang, S.-J., Jung, S.-Y., Lee, C.-H. \& Oh, T.-K. (2005b). Algoriphagus yeomjeoni sp. nov., isolated from a marine solar saltern in the Yellow Sea, Korea. Int J Syst Evol Microbiol 55, 865-870.

Yoon, J.-H., Kang, S.-J. \& Oh, T.-K. (2005c). Algoriphagus locisalis sp. nov., isolated from a marine solar saltern. Int J Syst Evol Microbiol 55, 1635-1639. 